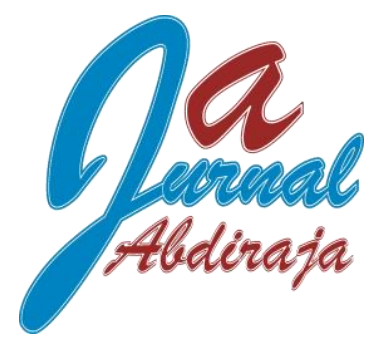

\section{PERBAIKAN KEMASAN DAN PELABELAN PRODUK KRIPIK SINGKONG MADURA UNTUK MEWUJUDKAN PELAKU USAHA MANDIRI MENYONGSONG TANTANGAN MASYARAKAT EKONOMI ASEAN YANG BERKELANJUTAN}

Volume 1, Nomor 1, September 2018

\author{
R.P. Much. Muchtar ${ }^{1}$ \\ Hidayat Andyanto \\ Moh. Zainudin ${ }^{3}$
}

Universitas Wiraraja

\begin{abstract}
The purpose of Science and Technology PLUS activities for the community is to improve the packaging and labeling of Kripik Singkong Madura Kipik Terbang Kuda Cassava Chips in Lanjuk Village, Manding District and Kripik Singkong Cap Baby in Pamolokan Village, Sumenep Sub-District, Sumenep Regency to realize independent business people to meet the challenges of a sustainable ASEAN economic community. The targets to be achieved are: a) Market-worthy modern packaging products with aluminum foil or appropriate plastic packaging, b) Labels include DINKES permits and MUI halal certification in accordance with regulatory provisions, c) Labels include product names, list of materials used and weight clean or clean contents in accordance with the provisions of the regulations, and d) Cassava chips business actors begin to be independent and ready to meet the challenges of the ASEAN Economic Community. The response of cassava chips entrepreneurs is quite varied, but there are also those who are appreciative and positive. Variation responses are, there are those who respond suspiciously, lack of appreciation and even tend to be "reluctant". After the entrepreneur follows the coaching, counseling, and coaching intensely and effectively with "face to face" and training, the entrepreneur is motivated to produce and improve the packaging and label of the cassava chips, and even dynamic packaging is always expected to change and grow. And even with improvements in packaging and labeling, they want to be able to penetrate a broader market, not just the local market.
\end{abstract}

Keyword: packaging, labels, independent businesses, halal certificates, madura cassava, ASEAN economic community

\title{
PENDAHULUAN
}

Tantangan yang dihadapi Indonesia pada era integrasi ekonomi ASEAN tidak hanya persaingan dengan negara sesama ASEAN dan negara lain di luar ASEAN, tetapi juga yang bersifat internal di dalam negeri termasuk kesiapan wilayah daerah kabupaten/kota. Demikian juga dengan pelaku usaha di Indonesia dan produknya, yang harus mampu bersaing dengan produktif dan berkesinambungan. Salah satu upaya agar mampu bersaing dan survive dalam era ini, maka semua permasalahan yang teridentifikasi, harus segera diselesaikan. Salah satu masalah yang muncul adalah kemasan yang justru selalu menjadi permasalahan bagi produk industri kecil dan menengah sektor makanan dan minuman. Walau pun dari sisi rasa dipandang cukup enak, tetapi karena kemasan tidak menarik, maka banyak produk yang tidak laku. Kemasan sebagai sarana komunikasi dan informasi dari suatu produk. Sehingga kemasan sebaiknya bersifat informatif, mempunyai label yang jelas, sesuai dengan peraturan label dan periklanan, dan menarik. Kemasan dari produk-produk kripik singkong Madura yang masih kurang baik, membuat produk ini sulit berkompetisi. Jika

\footnotetext{
1 mucha_atmo@yahoo.co.id

2 hidayat.andyanto@gmail.com

3 mohzein_mdr@yahoo.com
} 
kemasan produk tersebut tak segera diperbaiki, maka akan tergilas oleh produk sejenis atau komplementernya.

Selain kemasan, produk olah pangan, dalam pelabelan diwajibkan mencantumkan kadar gizi dan komposisi dari makanan yang diproduksi, sebagaimana tertuang dalam Pasal 2 Ayat (1) PP Nomor 69 Tahun 1999 Tentang Label dan Iklan Pangan. Lebih lanjut, dalam pencantuman label harus dilakukan sedemikian rupa sehingga tidak mudah lepas dari kemasannya, tidak mudah luntur atau rusak, serta terletak pada bagian kemasan pangan yang mudah untuk dilihat dan dibaca. Dan label itu berisikan keterangan mengenai pangan yang bersangkutan dan sekurang-kurangnya, berisi : (a) nama produk; (b) daftar bahan yang digunakan; dan (c) berat bersih atau isi bersih.

Masyarakat berhak untuk memperoleh informasi yang benar dan tidak menyesatkan mengenai pangan yang akan dikonsumsinya, yang disampaikan melalui label. Hal ini sebagaimana tertuang dalam penjelasan PP Nomor 69 Tahun 1999. Demikian juga pelaku usaha antara lain, dilarang memproduksi dan/atau memperdagangkan barang dan/atau jasa sebagaimana tertuang dalam Pasal 8 Ayat (1), huruf g, h, dan i UU No. 8 Tahun 1999 tentang Perlindungan Konsumen. Jika Pelaku usaha yang melanggar ketentuan sebagaimana dimaksud dalam Pasal 8 tersebut, diancam pidana penjara paling lama 5 (lima) tahun atau pidana denda paling banyak Rp 2.000.000.000,00 (dua miliar rupiah).

Keberadaan mitra Kripik Singkong Cap Kuda Terbang di Desa Lanjuk Kecamatan Manding dan Kripik Singkong Cap Baby Desa Pamolokan Kecamatan Kota, masih menggunakan kemasan lama, dan disamping itu label komposisi, pencantuman kedaluarsa, pencantuman keterangan halal tidak tepat, bahkan ada yang belum mendapatkan sertifikasi halal, sehingga dianggap perlu untuk melakukan perbaikan desain kemasan produk itu.

\section{METODE}

Ipteks PLUS untuk masyarakat dalam perbaikan kemasan dan pelabelan produk Kripik Singkong Madura Kripik Singkong Cap Kuda Terbang di Desa Lanjuk Kecamatan Manding dan Kripik Singkong Cap Baby Desa Pamolokan Kecamatan Kota, Kabupaten Sumenep untuk mewujudkan pelaku usaha mandiri menyongsong tantangan masyarakat ekonomi ASEAN yang berkelanjutan tersebut dilakukan dalam bentuk kegiatan sebagai berikut, yaitu (1) Sosialisasi dan Penyuluhan; (2) Pelatihan dan Pembekalan; (3) Pengajuan perijinan dan sertifikasi; (4) Mediasi dan konsultasi; (5) Pendampingan; dan (6) Monitoring dan Evaluasi.

\section{PEMBAHASAN}

Hasil yang dicapai pada kegiatan Ipteks Bagi Masyrakat ( $\left.\mathrm{I}_{\mathrm{b}} \mathrm{M}\right)$ PLUS pada kelompok mitra Kripik Singkong Cap Kuda Terbang dan Kripik Singkong Cap Baby, tidak bisa dilepaskan dari target dan luaran yang diharapkan. Adapun hasil yang dicapai dalam kegiatan $\mathrm{I}_{\mathrm{b}} \mathrm{M}$ ini sebagaimana diuraikan di bawah ini.

Pertama, Kemasan. Permasalahan yang ditemukan oleh Tim ketika melakukan pengamatan dan survey lapangan pada ke dua mitra tersebut, antara lain adalah kemasan kurang menarik, terkesan desain kemasan hanya dilakukan seadanya saja, gambar dan teks tercetak mudah lepas atau terkelupas, sehingga produknya terkesan jelek, bahkan selera konsumen menjadi hilang. Disamping itu, kemasan produk masih menggunakan plastik 
kualitas rendah dan dilakukan asal-asalan, hal ini tampak pada "sealing"yang mudah lepas atau sobek.

Atas dasar keadaan itu, Tim pada kegiatan ini, melakukan beberapa langkah secara intensif dan sabar, antara lain, melakukan sosialisasi dan motivasi, pendampingan, pembekalan dan pelatihan, serta monitoring dan evaluasi. Secara sabar dilakukan, karena untuk mempengaruhi dan mengubah sikap dan perilaku itu tidak semudah seperti membalik telapak tangan. Pada mulanya, tertangkap kesan oleh Tim, mitra bersikap cemburu dan curiga atas apa yang dilakukan oleh Tim. Dengan kesabaran dan dilakukan secara terusmenerus, maka Mitra akhirnya mulai melunak dan termotivasi, sehingga akhirnya mitra bersedia untuk mengadakan perubahan dan pembaharuan, terutama perubahan dan pembaharuan kemasan dan pengemasan. Hasil yang dicapai pada akhirnya adalah produk berkemasan modern laik pasar, estitis dan menarik serta disukai oleh konsumen. Dan mereka pun sudah memperbaiki teknik "sealing"atas produknya.

Kedua, Label dan Pencantuman nama produk, bahan dan berat atau isi bersih. Demikian juga, permasalahan lain yang ditemukan oleh Tim ketika melakukan pengamatan dan survey lapangan pada ke dua mitra tersebut, adalah pelaku usaha belum sadar hukum, sehingga dalam label produknya: (a) Belum mencantumkan ijin Depkes dan sertifikat halal secara benar, dan (b) Belum mencantumkan nama produk, daftar bahan yang digunakan dan berat bersih atau isi bersih secara benar. Walaupun ada mitra yang telah mencantumkan sertifikasi PIRT (Produksi Pangan Industri Rumah Tangga) Dinkes dan sertifikasi halal MUI (Majelis Ulama Indonesia), namun masih ada yang mencantumkan nama produk, daftar bahan yang digunakan dan berat bersih atau isi bersih tidak sesuai dengan ketentuan peraturan yang berlaku. Bahkan ada satu mitra yang belum mempunyai sertifikasi PIRT dan halal.

Demikian juga, Tim melakukan beberapa langkah secara intensif dan sabar, antara lain, melakukan sosialisasi dan motivasi, pendampingan, pembekalan dan pelatihan, serta monitoring dan evaluasi. Dengan upaya itu, akhirnya mitra telah bersedia mencantumkan nama produk, daftar bahan yang digunakan dan berat bersih atau isi bersih sesuai dengan ketentuan peraturan. Satu mitra (Kripik Kuda Terbang), yang sebelumnya tidak mempunyai PIRT, dengan bantuan dan fasilitasi Tim, akhirnya memperoleh nomor PIRT.

Ketiga, Sikap Pelaku usaha kripik singkong. Pengamatan dan observasi awal, Tim menemukan bahwa pelaku usaha kripik singkong bersikap konvensional, yang penting laku dijual, walaupun stagnan, tidak peduli bahwa hanya bisa dijual di tingkat lokal. Mereka berfikir bahwa laku tidaknya produknya itu merupakan rejeki dan nasib yang harus diterima, belum terpikirkan secara mendalam bagaimana produknya itu dapat bersaing secara luas, dan walaupun terlintas mereka belum tahu harus berbuat apa dan bagaimana caranya. Melihat kondisi semacam itu, akhirnya Tim melakukan beberapa langkah secara intensif dan sabar, antara lain, melakukan sosialisasi dan motivasi, pendampingan, pembekalan dan pelatihan, serta monitoring dan evaluasi. Dampak dari langkah-langkah yang dilakukan oleh Tim adalah pelaku usaha kripik singkong mulai bersikap mandiri yang siap menyongsong tantangan Masyarakat Ekonomi ASEAN. Bahkan mereka mulai berani, terbuka dan mengusulkan serta memohon pada Lembaga, Dinas/Instansi terkait untuk senantiasa dibimbing, dibantu, dan dibina dalam peningkatan usaha mereka itu. 
Keempat, Hasil lain yang dicapai. Respon konsumen atas perubahan atau perbaikan kemasan dan pelabelan sudah mulai tampak. Awal mula adalah beberapa konsumen memberikan respon ketertarikan, dan bertanya- tanya, antara lain, benarkah ini diproduksi di sini, benarkah produk ini aman, di mana produk ini bisa dibeli, dan lain-lain respon yang menunjukkan pengaruh atas perubahan kemasan dan label itu. Namun, berdasarkan observasi lanjut, walaupun respon itu berpengaruh kepada omzet penjualan, namun masih belum memberikan pengaruh yang signifikan atas peningkatan omzet penjualan.

Tim menilai bahwa respon itu masih bersifat terbatas, artinya bahwa pemasaran atau pengenalan atas perbaikan kemasan dan label itu tidak dilakukan secara luas. Atas dasar itu, Tim mengajukan usulan kepada Dinas Perdagangan dan Perindustrian Kabupaten Sumenep untuk membantu pemasaran produk yang dimaksud itu. Dan, setelah dilakukan fasilitasi secara intens, Dinas Perdagangan dan Perindustrian memberikan solusi dan tawaran untuk memasarkan produk mitra pada gerai "Wiraraja" milik Pemerintah Kabupaten Sumenep, dan menjajakan produk kripik itu di bagian depan dari Indomart atau Alfamart. Hal ini disambut positif oleh mitra, dan mitra merencanakan itu dan juga meminta bantuan mahasiswa.

\section{SIMPULAN}

Kesimpulan kegiatan perbaikan kemasan dan label direspon dengan baik dan antusias, walaupun dalam perjalanannya mengalami beberapa kendala, namun kegiatan ini dapat dilaksanakan dengan baik dan lancar. Adapun hasil yang dicapai pada kegiatan sampai saat ini, antara lain (1) Pengusaha menginginkan produknya berkemasan lebih baik dan laik pasar dengan kualitas baik (kedap udara), walauun tetap dengan menggunakan plastic; (2) Pengusaha menginginkan perbaikan pelabelan dan yang belum mencantumkan sertifikasi PIRT (Produksi Pangan Industri Rumah Tangga) Dinkes ingin mencantumkannya dalam kemasan mereka. Pada kemasan mereka telah mencamtumkan label dan kemasan telah dibuat menarik. Disamping itu, pengusaha juga menginginkan pencantuman sertifikasi halal MUI (Majelis Ulama Indonesia) sesuai dengan ketentuan peraturan, dan yang belum mempunyai mulai berkeinginan untuk mengurus sertifikat ini; (3) Pengusaha mulai tertarik untuk mencantumkan nama produk, daftar bahan yang digunakan dan berat bersih atau isi bersih sesuai dengan ketentuan peraturan; dan (4) Dinas Perdagangan dan Perindustrian memberikan solusi dan tawaran untuk memasarkan produk mitra pada gerai "Wiraraja" milik Pemerintah Kabupaten Sumenep, dan menjajakan produk kripik itu di bagian depan dari Indomart atau Alfamart.

\section{DAFTAR RUJUKAN}

Lynton, R.P. dan Pareek, U. 1998. Pelatihan dan Pengembangan Tenaga Kerja. Pustaka Binaman: Jakarta.

Republik Indonesia. 1945. Undang-Undang Dasar Negara Republik Indonesia Tahun 1945 dan Seluruh Amandemennya.

Republik Indonesia. 1999. Peraturan Pemerintah Republik Indonesia Nomor 69 Tahun 1999 tentang Label dan Iklan Pangan.

Republik Indonesia. 1999. Undang-Undang Republik Indonesia Nomor 8 Tahun 1999 tentang Perlindungan Konsumen. 
Republik Indonesia. 2001. Peraturan Pemerintah Republik Indonesia Nomor 58 Tahun 2001 tentang Pembinaan Pengawasan dan Penyelenggaraan Perlindungan Konsumen.

Republik Indonesia. 2005. Peraturan Kepala Badan Pengawas Obat dan Makanan Republik Indonesia Nomor HK.00.06.51.0475 tentang Pedoman Pencantuman Informasi Niilai Gizi PADA Label Pangan. 